\title{
The main types of mental information processing: a systematic structural method
}

\section{Las direcciones básicas del procesamiento de la información mental: un enfoque sistémico-estructural}

\author{
Tsupikova Elena \\ Siberian State Automobile and Highway Academy, Omsk, Russian Federation \\ ORCID ID: https://orcid.org/0000-0002-7849-4843 \\ Tyutchenko Alexander \\ Moscow city pedagogical University, Moscow, Russian Federation \\ ORCID ID: https://orcid.org/0000-0002-6143-5900 \\ Katsyuba Larisa \\ Peoples' Friendship University of Russia (RUDN University), Moscow, Russian \\ ORCID ID: https://orcid.org/0000-0002-3824-5535
}

Received 10-10-20 Revised 11-12-20 Accepted 01-13-21 On line 01-14-21

*Correspondence

Email: olfiss@list.ru
Cite as:

Tsupikova, E., Tyutchenko, A., \& Katsyuba, L. (2021). The main types of mental information processing: a systematic structural method. Propósitos y Representaciones, 9 (SPE1), e858. Doi: http://dx.doi.org/10.20511/pyr2021.v9nSPE1.858 


\section{Summary}

The article describes the main types of mental information processing in the context of a systematic structural method. The author analyses the semantic theories of information. The author reviews the mechanisms of information processing and its qualitative properties. The article describes the mechanism of textual presupposition accommodation.

Keywords: mental operations, information, knowledge.

\section{Resumen}

El artículo en el marco de un enfoque sistémico-estructural describe las principales direcciones del procesamiento de la información mental. El artículo analiza las teorías semánticas de la información, examina los mecanismos de procesamiento de la información y sus características cualitativas, describe los mecanismos para restaurar la presuposición del texto.

Palabras clave: operaciones mentales, información, conocimiento.

\section{Introduction}

The mental operations have been analyzed for a long time. However, the scientific data published by PISA (Programme for International Student Assessment) in the early XXI century made the teaching forms, methods and techniques for understanding the read information especially relevant. The research demonstrated that students have poor text navigation skills; they were unable to pick up and use information from a text. In order to change the situation, new teaching methods should be developed to provide a skill of reading for understanding. The ability to understand and interpret the read information, i. e. mental information processing, is linked to the conceptual structures of consciousness. "The higher the level of the conceptual structures, the stronger its influence on the structure and functioning of an individual intelligence" (Kholodnaya 2012, p.96).

Mental information processing is an important psychophysical process that determines the quality of education at school and university. The research on mental information processing offers the prospect of upgrading psychodidactics of educational systems for children and adults (Weber, Molen, Molenaar (1994); Tarvainen, Ranta-aho, Karjalainen (2002); Kholodnaya, Shcherbakova, Gorbunov, Golovanova, Papovyan, 2013; Kosslyn, 2011; Zheng, Jiang, Tien, Meneghetti, Panton, Atkins, 2012; Durantin, Gagnon, Tremblay, Dehais, 2014; Luque-Casado, Perales, Cardenas, Sanabria, 2015; Wang, Hao, Ku, Grabner, Fink, 2017). That is what makes the research on the process of interpreting information in the context of a systematic structural method so relevant.

\section{Review}

\section{The main types of mental information processing}

The educational paradigm based on an assumption that a student must obtain a store of knowledge, vast enough for a successful life, has reached its limits. A professor, oriented to a simple information transmission instead of transmitting reliable algorithms of understanding and assessing information, increases the requirements for the acquired store of knowledge. The attempts professors make to foresee students' life choices and provide them with a sufficient store of knowledge also make educational material more complicated and expanded.

Meanwhile, the main purpose of higher education is not to accumulate information, but to develop students' intelligence, i.e. to form knowledge, skills and mental abilities. "The basic 
meaning of intelligence is creating a special type of representations related to the producing of objective knowledge of the world", 'the distinctive features of an intellectual person's store of knowledge....are its high diversity and structure, high flexibility and quick update every time a new environment requires it, a generalized way of its representation...» (Kholodnaya 2002, p.12).

The demands of the today's society (an effective and high-quality formation of a new type specialist's identity) lead to more complicated and expanded pedagogic goals and level of educational resources. As a result, students have to study harder to get a higher quality of education and become exhausted; to overcome this, the educational process should be optimized, i. e. maximum results in forming knowledge, skills and mental abilities should be achieved with minimum time, effort and means of achieving certain goals (Babanskiy \& Ptashnik 1982, p. 66$67)$.

A special attention was always paid to the problem of knowledge as the result of education and life experience. Many scholars studied knowledge as the result of productive thought (R. Katz, J. Piaget, Yi. Huang, E. Becker, K. Rashpe). L. Székely was the first one to conduct an experimental research on the topic. Its main conclusion was the fact that verbal knowledge, learnt by heart, often turns out to be untenable and functionally invalid (Székely 1965, p.362).

Knowledge is a conceptual system. The concepts exist in the mind as associated ideas that should not be transferred in such a form: "knowledge is not transferred... It is formed in a person's mind as a result of his activity" (Bel'diyan 2002, p.3). The information about knowledge is transmitted during educational process.

The mental information processing has a complex epistemological nature. It can be described from different points of view: observation (the idealists), research (the dualists, combining two correlated cognitive models, compared in the terms of the subjective and the objective), and action (the materialists that prove theoretical aspect of information in practice). Mental information processing passes the abovementioned stages subsequently.

The scheme of an individual's mental information processing has been preceded by the following presuppositions:

1) Life and the structures, able to obtain and accumulate information, appear at the same time, "life is a process of acquiring information" (Lorenz), cognition is a life function;

2) each and every living creature has a system of a so-called "priory" cognitive structures from their birth, formed according to the evolution theory; as a result of the selection, the structures adequate enough for the environment and the survival, get entrenched in the mind. J. Piaget (1969) states that an individual reacts to the information from the environment according to their database. New data are transformed to get adapted to the existent intellectual schemes. At the same time the schemes get adapted to activate new data and become transformed, too.

Information can be represented in a textual, graphical, digital or audial format. A message is one of the forms of information. It is the information which should be transmitted in a certain format. When assessing a piece of information, its newness should be regarded as the qualitative parameter because it is the result of uncertainty about an object, a phenomenon or a process, and uncertainty can be measured.

Norbert Wiener (2001), the American researcher, tried to create a semantic theory of information. The concept is that the recipient of information should have a certain store of knowledge to understand and use information. Indeed, full ignorance of the object makes extracting scientific information from the message impossible. The more we learn about the object, the more information we can extract from the message. 
If we consider a recipient's knowledge about an object to be a sort of thesaurus consisting of semantically related ideas, the names of objects, then the amount of information in a message can be assessed by the changes of an individual's thesaurus after the message. In other words, the vaster a recipient's thesaurus is, the more semantic information can be extracted.

Let us study the mechanisms of information processing.

\section{The mechanism of information processing}

When analyzing a new piece of information, first of all, a recipient identifies and assesses it in the terms of quality and quantity (Figure 1).

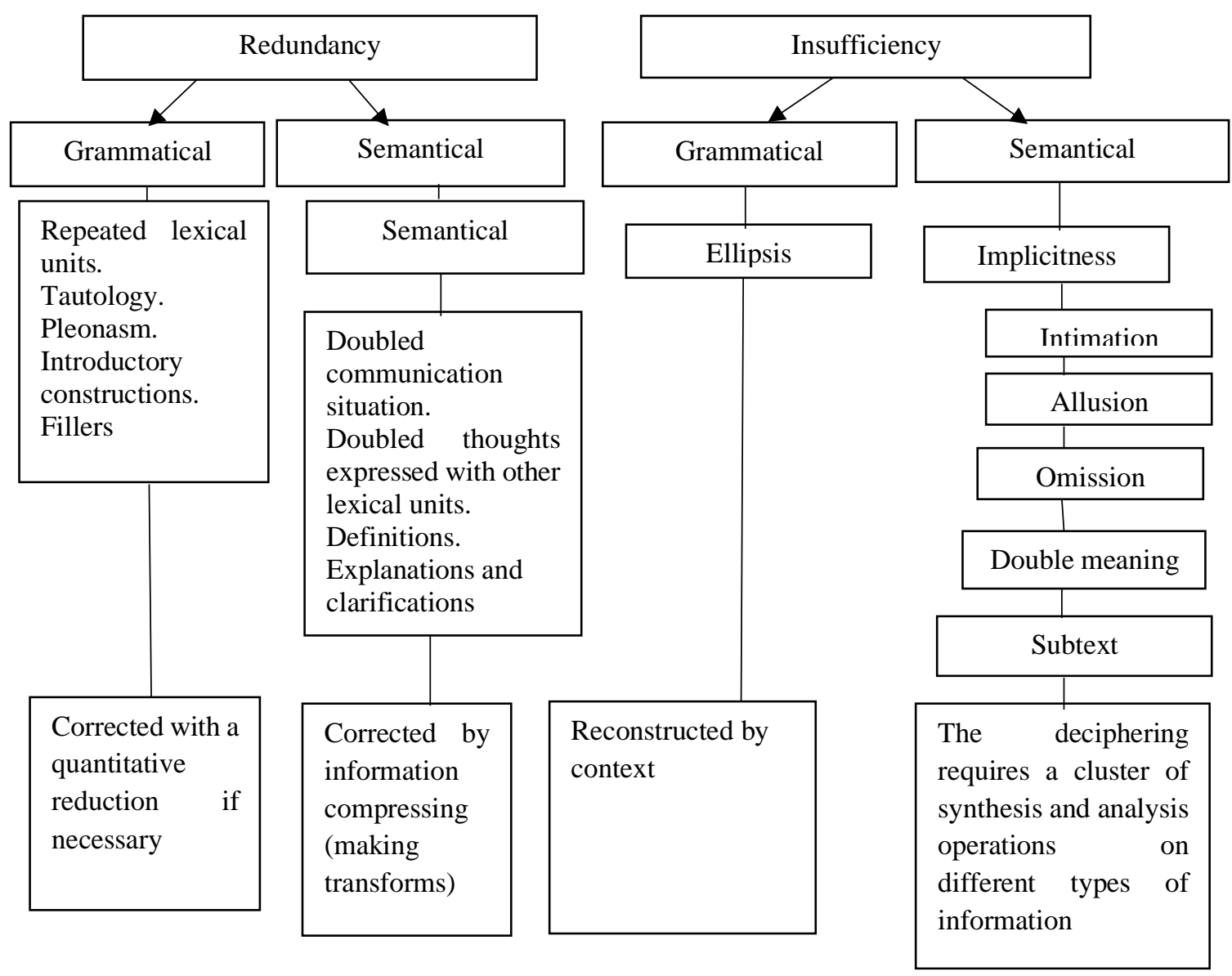

Figure 1. Redundancy and insufficiency of information in the text

Redundancy is a fully or partly repeated message which follows new information, proving and correcting our predictions. Its degree differs from one type of communication to another: a full redundancy suggests no new information; a minor redundancy is a hazard for understanding the message because of information overload. Nonetheless, this parameter is highly individual: the attitude to its degree differs from person to person.

The compression of information always leads to its reinterpretation as a new form would have its own additional message. Though a compressed message does not contain a full text message, in many cases it can be unfold in a wide range of forms.

The ideas of redundancy and insufficiency of information can be expressed with the terms of explicitness and implicitness which, in their turn, can be determined with the concept of understanding. 
Redundancy of information results in predictability. Predictability as a property of communication is the ability to predict the next element of a message and anticipate it from prior communication experience.

Insufficiency of information may arise for several reasons: 1) the presupposition is unfamiliar to the recipient; 2)the recipient has a certain fixed presupposition in a form of a prejudice; 3 ) the prediction turns out to be incorrect; 4) the ellipsis turns out to be misinterpreted (because of a speaker's abrupt manner of speaking); 5) homonymic lexical units or constructions cannot be interpreted without a wider context; 6) the recipient is unaware of the specifics of concept expression in the language; 7) the recipient is unable to understand stylistic means and techniques.

Each of the reasons above makes the information disorganized and, as a result, must be taken into consideration in the context of speech producing and interpreting.

\section{method. \\ The qualitative properties of information in the context of a systematic structural}

The qualitative properties of information are the following:

1. Objectivity. Information is the reflection of reality which exists regardless of our conscience and desire.

2. Reliability. The information is reliable if it reflects the true situation.

Information is non-reliable if:

1) there is a deliberate distortion (disinformation);

2) there is a distortion caused by some sort of interferences;

3 ) the value of the real fact is exaggerated or underestimated.

3. Completeness. Information is complete if there is enough information for a person to understand and make further decisions.

4. Relevance (timeliness) means importance and materiality for now. It is relevant information that may be of real use. Information is irrelevant if it is outdated or unnecessary and useless.

5. Usefulness/uselessness. Usefulness of information is valued according to the goals we can achieve by using it.

6. Logical organization.

The additional properties of social information is, firstly, its semantical (conceptual) nature, i. e. an ideal nature, as it is ideas that generalize the most essential features of all objects, processes and phenomena. Secondly, it is linguistic nature. The more time passes, the bigger gets the amount of information; it is accumulated, systematized, assessed and generalized. This property is called information growth and accumulation. Thirdly, outdated information loses its relevance as time passes. It is not time itself that makes information irrelevant, but new information that fully or partly clarifies, updates or denies the previous one.

The abovementioned properties of information allow us not only to reflect on the structure of information thesaurus, but also to develop potential algorithms of information processing.

\section{The stages of transforming information into knowledge}

Information is a linear (verbal information) or a non-linear (visual information) system of signs, transmitting a message, which a recipient perceives and identifies, and correlating with certain concepts in the interlocutors' mind (Bel'diyan 2002, p.3). However, while information can be identified with an idea as a result of perceiving a chain of signs, knowledge is a system of transformed ideas, a system of transforming one idea into another. While teaching, a professor 
transmits twofold information: the message itself and the way of transforming the information into knowledge. The informative function may be transferred with educational technical devices, whereas the organizing function may be implemented only by the professor themselves.

The transformation of informative (textual) semantics into knowledge undergoes several stages. V.M. Bel'diyan stresses the following stages:

1) restructuring outdated knowledge to analyze new information;

2) building new skills: conceptually, a skill is an external analogue of an idea. Ideas are based on the generalization (turning from the particular to the general with further specification);

3) differentiating new and the previous ideas;

4) concluding from the formed ideas. The internal (thinking) readjustment of ideas to new information results in acquiring knowledge as a system of interrelated concepts. The concept itself is a system of transforming ideas, which correlate with variant/invariant relations among the objects of the activity (Bel'diyan 2007). Let us demonstrate a more specific scheme (Figure 2):

\begin{tabular}{|c|c|}
\hline Information - idea & \\
\hline \multirow[t]{2}{*}{ Restructuring outdated knowledge } & \\
\hline & $\begin{array}{l}\text { Transforming the previous knowledge } \\
\text { because of new information }\end{array}$ \\
\hline $\begin{array}{l}\text { Differentiating new ideas and those } \\
\text { associated with them }\end{array}$ & \\
\hline Building a new skill & \\
\hline Concluding from the previous ideas & \\
\hline Knowledge (a system of transformed ideas) & \\
\hline
\end{tabular}

Figure 2. The stages of transforming information into knowledge

\section{Textual and communicative presupposition accommodation}

Presupposition is additional knowledge, a six-seventh of a message, not expressed in the speech. Presupposition accommodation provides understanding the semantics of the text, as well as checking the reliability and veracity of information (Figure 3 ).

\begin{tabular}{|l|l|}
\hline \multicolumn{1}{|c|}{ Type of presupposition } & \multicolumn{1}{c|}{ Analytic and synthetic operations } \\
\hline 1. Experience & $\begin{array}{l}\text { The analysis of the speech in the context of correspondence to the } \\
\text { previous knowledge }\end{array}$ \\
\hline 2. Facts - new information & $\begin{array}{l}\text { A different, non-reasoned explanation of one and the same case at the } \\
\text { different stages of communication (a different explanation is the result of } \\
\text { forgotten previous versions) }\end{array}$ \\
\hline
\end{tabular}




\begin{tabular}{|c|c|}
\hline $\begin{array}{l}\text { 3. The absence of } \\
\text { contradictions }\end{array}$ & The search for any contradictions and resolution of the uncertainties \\
\hline $\begin{array}{l}\text { 4. Psychological profile of } \\
\text { the recipient }\end{array}$ & $\begin{array}{l}\text { Excessive precision (=seem coached) and a match in each detail in the } \\
\text { stories of the respondents. } \\
\text { The absence of minor details (a clear sign of the absence of the } \\
\text { experience) }\end{array}$ \\
\hline $\begin{array}{l}1 \text { and } 4 \text { at the same time } \\
\text { (forming a psychological } \\
\text { profile of the recipient } \\
\text { according to their typical } \\
\text { behavior mechanisms) }\end{array}$ & $\begin{array}{l}\text { Only positive information about themselves and no doubts about the } \\
\text { narrative. } \\
\text { Persistently and repeated statements (an Eastern parable: you said it once } \\
\text { and I believed; you said it twice and I began to doubt; you said it three } \\
\text { times and I became fully convinced that you lied). } \\
\text { Slips of the tongue (telling the truth accidentally). } \\
\text { The phrases unusual for the speaker. } \\
\text { Too sketchy or exaggerated, put-on emotions. } \\
\text { Inappropriate repeated references to their decency and altruistic motives. } \\
\text { Avoiding answering the questions trying to pretend that the question was } \\
\text { misunderstood or forgotten. } \\
\text { Concealment of the information the speaker would never know or } \\
\text { forgetfulness in the context of relatively significant memories. }\end{array}$ \\
\hline
\end{tabular}

Figure 3. The mental operations on presupposition accommodation

In order to accommodate presupposition and identify the qualitative properties of information one may use reflexive hearing techniques. They help:

1) checking whether understanding of one's statements is correct

2) analyzing the speaker's statements and motives (one should agree with the speaker's spontaneous speech).

3) demonstrating the interest in the information.

\section{Conclusions}

The research proved that textual information processing is a complex mental process related to the transforming information into knowledge. follows:

The textual information processing undergoes several stages which we summarize as it

1) The meaning of a text, as we know, consists of three elements: semantics, syntactics, and pragmatics. Presupposition is a correlation between the meaning of the text and the objective reality. 
2) The analysis of semantics of the text (the quantative and qualitative aspects of concepts and their interrelations) is provided with logical operations with the terms of quantity, quality and the definition of the concept.

3) The analysis of concepts and their interrelations and identification of logic impairment; a graph-based logic scheme, reliability of information and the absence of contradictions: logic (denotation predicate analysis), the analysis of judgements in the text (analogy, the reason and the sequence, subsequence and simultaneity), the analysis of logic impairments and identification of their reasons and purposes, semantics (presuppositions), axiology (i.e., the influence through cultural relations).

4) The identification of the level of redundancy and insufficiency of information (differentiating new and the previous information), its reliability, validity and usability: the psychological predicate is analyzed and synthesized, thus, it is protected from possible manipulations.

5) Synthesis: the presentation of information in a form of a new, upgraded text, the readjustment of a text logic, presupposition accommodation (estimating the level of entropy what new follows the information and what new problems it raises).

\section{References}

Babanskiy, Yu.K. \& Ptashnik M.N. (1982) Optimizatsiya pedagogicheskogo protsessa (V voprosakh i otvetakh) [The optimization of teaching process (questions and answers)]. Kiev, Ukraine, 198

Bel'diyan, V.M. (2002) Obshchaya lingvistika [General linguistics]. Moscow, Russia, 446

Benvenist E. (1966) Problèmes de linguistique générale. Paris: Gallimard, coll. «Bibliothèque des sciences humaines», 357 (Russ. ed.: Benvenist E. Obshchaya lingvistika [General linguistics]. Moscow, Russia, 447)

Durantin, G. \& Gagnon, J.-F. \& Tremblay, S. \& Dehais, F. (2014) Using near infrared spectroscopy and heart rate variability to detect mental overload. Behavioural brain research, 16-23

Kholodnaya, M.A. \& Shcherbakova, O.V. \& Gorbunov I.A. \& Golovanova I.V. \& Papovyan M.I. (2013) Informatsionno-energeticheskie kharakteristiki razlichnykh tipov kognitivnoy deyatel'nosti. [The information and energy characteristics of different cognitive activities]. Psikhologicheskiy zhurnal, Vol. 34, No 5, 96-100

Kholodnaya, M.A. (2002) Psikhologiya intellekta. Paradoksy issledovaniya. [The psychology of intellect: the research paradoxes], Saint Petersburg, Russia, 264

Kholodnaya, M.A. (2012) Psikhologiya ponyatiynogo myshleniya: Ot kontseptual'nykh struktur $\mathrm{k}$ ponyatiynym sposobnostyam. Moscow, Institute of psychology Russian academy of sciences, 288

Kosslyn, S. (1982) Image and Mind. The American Journal of Psychology, Vol. 95, No 1, 172176 (Russ. ed.: Kosslin S. Myslennye obrazy [Mental imagery]. Kognitivnaya psikhologiya: istoriya i sovremennost'. Khrestomatiya. Falikman M., Spiridonova. V. (eds.). Moscow, Russia, 2011, 288-292

Luque-Casado, A. \& Perales, J.C. \& Cardenas, D. \& Sanabria, D. (2015) Heart rate variability and cognitive processing: the autonomic response to task demands. Biol. Psychol. 113, 8390

Piaget, J. (1947) La psychologie de l'intelligence. La genèse du nombre chez l'enfan. Logic and Psychology. Russ. ed.: Piazhe Zh. Izbrannye psikhologicheskie trudy. Psikhologiya intellekta. Genezis chisla i rebenka. Logika i psikhologiya [The Psychology of Intelligence. The Child's Conception of Number. Logic and Psychology: Selected Works]. Moscow. Prosveshcheniye, 659

Székely, L. (1965) Knowing and Thinking (Russ. ed.: Sekey L. Znanie i myshlenie. Psikhologiya myshleniya. Moscow, Russia, 343-364) 
Tarvainen, M. P. \& Ranta-aho, P. O. \& Karjalainen, P. A. (2002). An advanced detrending method with application to HRV analysis. Biomedical Engineering, IEEE Transactions on, 49(2), 172 -175 http://doi.org/10.1109/10.979357

Wang, M. \& Hao, N. \& Ku, Y. \& Grabner, R.H. \& Fink, A. (2017) Neural correlates of serial order effect in verbal divergent thinking. Neuropsychologia. 2017, 92- 100

Weber, E. J. \& Van Der Molen, M. W., \& Molenaar, P. C. M. (1994). Heart rate and sustained attention during childhood: Age changes in anticipatory heart rate, primary bradycardia, and respiratory sinus arrhythmia. Psychophysiology, 31(2), 164-174. http://doi.org/10.1111/j.1469-8986.1994.tb01036

Wiener, N. (1950) The Human Use of Human Beings. Cybernetics and Society. London, Eyre \& Spottiswoode, 1950, 241 (Russ. ed.: Viner N. Chelovek upravlyayushchiy [The Manager]. Saint Petersburg, Russia, 2001, 196

Zheng, B. \& Jiang, X. \& Tien, G. \& Meneghetti, A. \& Panton, O. N. \& Atkins, M. S. (2012). Workload assessment of surgeons: correlation between NASA TLX and blinks. Surgical Endoscopy, 26(10), 2746-2750. http://doi.org/10.1007/s00464-012-2268-6

*This paper has been supported by the RUDN University Strategic Academic Leadership Program. 